\title{
Evolution of aerosol optical thickness over Europe during the August 2003 heat wave as seen from CHIMERE model simulations and POLDER data
}

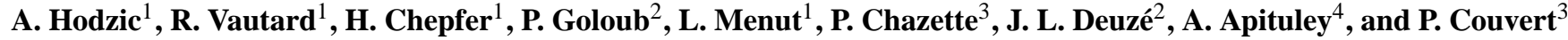 \\ ${ }^{1}$ Laboratoire de Météorologie Dynamique, Institut Pierre-Simon Laplace, Palaiseau, France. \\ ${ }^{2}$ Laboratoire d'Optique Atmosphérique, Lille, France. \\ ${ }^{3}$ Laboratoire des Sciences du Climat et de l'Environnement, Institut Pierre-Simon Laplace, Gif sur Yvette, France. \\ ${ }^{4}$ National Institute of Public Health and the Environment, The Netherlands.
}

Received: 16 February 2005 - Published in Atmos. Chem. Phys. Discuss.: 27 June 2005

Revised: 21 February 2006 - Accepted: 15 March 2006 - Published: 30 May 2006

\begin{abstract}
This study describes the atmospheric aerosol load encountered during the large-scale pollution episode that occurred in August 2003, by means of the aerosol optical thicknesses (AOTs) measured at $865 \mathrm{~nm}$ by the Polarization and Directionality of the Earth's Reflectances (POLDER) sensor and the simulation by the CHIMERE chemistrytransport model. During this period many processes (stagnation, photochemistry, forest fires) led to unusually high particle concentrations and optical thicknesses. The observed/simulated AOT comparison helps understanding the ability of the model to reproduce most of the gross AOT features observed in satellite data, with a general agreement within a factor 2 and correlations in the 0.4-0.6 range. However some important aerosol features are missed when using regular anthropogenic sources. Additional simulations including emissions and high-altitude transport of smoke from wildfires that occurred in Portugal indicate that these processes could dominate the AOT signal in some areas. Our results also highlight the difficulties of comparing simulated and POLDER-derived AOTs due to large uncertainties in both cases. Observed AOT values are significantly lower than the simulated ones (30-50\%). Their comparison with the ground-based Sun photometer Aerosol Robotic Network (AERONET) measurements suggests, for the European sites considered here, an underestimation of POLDER-derived aerosol levels with a factor between 1 and 2. AERONET AOTs compare better with simulations (no particular bias) than POLDER AOTs.
\end{abstract}

Correspondence to: A. Hodzic
(hodzic@lmd.polytechnique.fr)

\section{Introduction}

During the first half of August 2003 a severe heat wave hit Western and Central Europe (Rasool et al., 2004). The persistent anticyclonic conditions characterized by exceptionally high temperatures were favorable to the development of a large-scale photochemical pollution episode (Vautard et al., 2005). The stagnation of the air mass also led to the accumulation of the primary emitted particulate matter (PM) and the development of secondary aerosols. Furthermore, in conjunction with the dry, hot weather conditions, the Southern part of Europe was influenced by significant forest fires that generated a huge amount of primary particles.

Modeling such a wide pollution episode is a challenging problem because models have to deal with an exceptional environment for which their parameterizations are not necessarily appropriate. For instance the formulation of classical models of dry gaseous deposition or biogenic emissions do not generally account for the exceptional deficit in soil water. When using standard anthropogenic emission inventories chemistry-transport models (CTMs) probably underestimate the evaporation of anthropogenic non-methane volatile organic compounds due to extremely high temperatures. For aerosols the drought increases the erodibility of soils and favors forest fires, phenomena which are generally not taken into account in an accurate manner in these standard emissions. Therefore in such extreme weather conditions there is a large degree of uncertainty in aerosol sources and physical parameterizations, leading to significant difficulties for CTMs to simulate the aerosol distribution and there is a strong need for the models to be tested against observations in such cases.

The use of satellite measurements to assess model performance in simulating aerosol spatial distributions at regional scale offers a great advantage due to their wide spatial cover-

Published by Copernicus GmbH on behalf of the European Geosciences Union. 
age. Long-term comparisons between satellite retrieved and model simulated aerosol optical properties have already been performed using global scale models in several studies (Chin et al., 2002; Yu et al., 2003; Matsui et al., 2004), but such a comparison has not been carried out at regional scale, with a much higher spatial resolution (typically 4-8 times).

The retrieval of aerosol optical thickness from satellite measurements has been attempted several times (Kaufman et al., 2002). Depending on the measurement technique the aerosol detection is often restricted to specific regions or types of aerosols. In the first studies, the aerosol remote sensing was performed using a single wavelength and single angle of observation sensors, such as AVHRR (Advanced Very High Resolution Radiometer), METEOSAT and GOES (Geostationary Operational Environmental Satellite). Measurements performed by the TOMS (Total Ozone Mapping Spectrometer) instrument were based on two wavelengths and allowed the monitoring of the transport of elevated smoke or dust layers. However, the detection by TOMS of the aerosol load over several regions known to be highly polluted was limited (Chiapello et al., 2000; Tanré et al., 2001). The POLDER (Polarization and Directionality of the Earth's Reflectances, Deschamps et al., 1994) sensor was the first instrument designed for the aerosol monitoring over land and ocean (Herman et al., 1997). The measurement technique is based on the combination of two spectral channels as well as the observation of the state of polarization of the light when reflected by atmosphere and ground. Despite this recent progress in remote sensing of aerosols, quantitative retrieval of aerosol loads above land surfaces remains challenging because the aerosol signature is small compared to the surface reflectivity. POLDER-1 (1997) and POLDER2 (2003) collected respectively 8 and 7 months of observations and a new generation satellite instrument (PARASOL) was successfully launched in fall 2004. Other recent sensors, such as ATSR and MODIS (Moderate-resolution Imaging Spectroradiometer) are also producing maps of aerosols (Remer et al., 2002); even if the time overlap between those missions is still insufficient, inter-comparisons between aerosols properties derived from these different missions (Goloub and Arino 2000; King et al., 1999; Myhre et al., 2004) allowed improvements of aerosol retrievals. In comparison to other sensors, POLDER takes advantage of light polarization to detect fine aerosols over the land.

The aim of this study is threefold. First of all we describe the aerosol optical depth evolution during the $\mathrm{Au}-$ gust 2003 heat wave, using the POLDER sensor measurements and simulations from the CHIMERE (Schmidt et al., 2001; Bessagnet et al., 2004) regional CTM. Second the intercomparison between POLDER optical depth, simulated optical depth, and the equivalent values obtained by Sun photometers belonging to the AErosol RObotic NETwork (AERONET) (Holben et al., 1998) helps validating the CHIMERE model, which contains a detailed aerosol formulation (Bessagnet et al., 2004), and helps understand- ing its main deficiencies and the gaps in our knowledge about aerosol processes. Finally this intercomparison also helps understanding problems present in the satellite measurements and in the algorithms used to derive the atmosphere's content properties.

In the following sections, data sets issued from both satellite and ground-based measurements are presented, and the AOT retrieval methods are described (Sect. 2). The CHIMERE model description and simulations are presented in Sect. 3. The comparison results between model and satellite data are discussed in Sect. 4 and finally, the origins of the model discrepancies are identified. Section 5 contains our conclusions.

\section{Aerosol data and retrieval methods}

Measurements used in this study are retrieved from both POLDER remote sensing and AERONET ground-based measurements.

\subsection{POLDER data and retrieval methods}

The POLDER instrument on board the ADvanced Earth Observation Satellite (ADEOS-2) was operational for 7 months between April and October 2003 (Deschamps et al., 1994). The sensor is a wide field of view imaging radiometer that provides simultaneous measurements of spectral, directional and polarized radiance in the visible domain over land and ocean with a local overpass time around 10:30 a.m. over Europe. The retrieval of aerosol optical properties from POLDER-2 is different over ocean and land surfaces. Over the ocean, the inversion scheme uses the spectral variability of the total radiances between the 865 and $670 \mathrm{~nm}$ channels (Deuzé et al., 2000). Over land, where the surface contribution to the total radiance is generally large, aerosol retrieval is based on a best fit between measured polarized radiances and those simulated for different aerosol types (varying aerosol algorithm and optical thickness) and surface conditions (Herman et al., 1997; Leroy et al., 1997; Deuzé et al., 2001). As the largest particles generate low polarization ( $\mathrm{Li}$ et al., 2004), only the optical characteristics of the accumulation mode (radius $<0.6 \mu \mathrm{m}$ ) are derived. Thus, coarse or non spherical particles, such as desert dust are not detected by the POLDER sensor because they polarize the natural light 5-10 times less than anthropogenic aerosols in the scattering angles used for the retrieval. A lognormal size distribution is assumed and the aerosol refractive index is fixed to $\mathrm{m}=1.47-0.01 \mathrm{i}$ based on climatology (i.e, single scattering albedo ranging from 0.85 to 0.95 depending on the size distribution). Over land surfaces (except for desert regions), considering all AERONET sites available during the global validation exercise, departure between satellite and ground-based accumulation aerosol optical thickness has been shown to be less than $20-30 \%$ when 



Fig. 1. Fine-mode Aerosol Optical Thickness obtained from POLDER-2 data at $865 \mathrm{~nm}$ during the August 2003 heat wave episode (from 1 to 15 August). 
Table 1. POLDER-2 mean AOT values from April to October 2003.

\begin{tabular}{lccc}
\hline Months & Mean AOT & $\begin{array}{c}\text { Standard } \\
\text { Deviation }\end{array}$ & $\begin{array}{c}\text { Number of } \\
\text { Data (grid cells) }\end{array}$ \\
\hline Apr. & 0.046 & 0.0066 & 1752969 \\
May & 0.031 & 0.0049 & 1217425 \\
June & 0.039 & 0.0054 & 1683926 \\
July & 0.034 & 0.0066 & 1810997 \\
Aug. & 0.052 & 0.0072 & 3138817 \\
4th-13th & 0.064 & 0.0136 & 1496892 \\
16th-31st & 0.041 & 0.0081 & 1212944 \\
Sep. & 0.028 & 0.0041 & 2119962 \\
Oct. & 0.022 & 0.0031 & 716878 \\
\hline
\end{tabular}

medium and high anthropogenic or biomass burning aerosol loadings are considered. Discrepancies could reach 100\% and more when small AOT occurs simultaneously with inaccurate surface modelling. Over the ocean, the retrieval errors of the accumulation aerosol optical thickness are less than $15 \%$ when corresponding optical thickness exceeds 0.08 at $670 \mathrm{~nm}$.

In this study, we use the POLDER Level-2 AOT data at $865 \mathrm{~nm}$ and Angström exponent coefficients derived from AOT at 670 and $865 \mathrm{~nm}$, corresponding to aerosol fine mode (radius less than $0.6 \mu \mathrm{m}$ ) and including anthropogenic aerosols, smoke and dust fine fraction. Data are cloud screened. Finally, for all model/observation comparisons, we average POLDER data over each cell of the CHIMERE regional $0.5^{\circ} \times 0.5^{\circ}$ longitude-latitude grid.

\subsection{AERONET ground-based measurements}

The aerosol optical depth is also measured by ground-based CIMEL Sun photometers in the AErosol RObotic NETwork (AERONET; Holben et al., 1998). For comparisons with model and POLDER data, AOT data at $870 \mathrm{~nm}$ corresponding to the POLDER overpass and to clear-sky conditions according to the POLDER cloud mask, have been selected in the AERONET database at 14 European monitoring sites (see Fig. 7b). As for the POLDER data, the AERONET measurements retained for the comparison only account for the aerosol fine mode.

\section{Model simulations}

\subsection{General configuration}

In this study atmospheric aerosols are simulated using a regional version of the chemistry-transport model CHIMERE that calculates the concentrations of both inorganic and organic aerosols of primary and secondary origin, including primary particulate matter, mineral dust, sulfate, nitrate, am- monium, secondary organic species and water. The aerosol population is represented using a sectional size distribution considering 11 size bins geometrically spaced from $10 \mathrm{~nm}$ to $20 \mu \mathrm{m}$ diameter and particles internally mixed in each size section. Detailed description of the model configuration and performances over Europe are presented in previous studies (Bessagnet et al., 2004; Vautard et al., 2005). The simulation domain covers Western Europe, with a 0.5 degree horizontal resolution and 14 vertical sigma-pressure levels extending up to $500 \mathrm{hPa}$. The model inputs, including meteorological fields, anthropogenic emissions and boundary conditions are identical to those used in Vautard et al. (2005). The simulations are performed from 25 July to 15 August 2003, with a prior 5 day initialization spin-up run. For the comparison, the model outputs are taken at 11:00 UTC, corresponding to the satellite overpass time over Europe, and only when the cloud screened POLDER data are available.

\subsection{Aerosol optical thickness simulation}

The aerosol optical properties are estimated from model outputs following the method described in Hodzic et al. (2004). All aerosols contributing to the optical thickness are assumed to be accounted for by the model. Given the simulated aerosol size distribution and mass concentrations, the aerosol optical thickness is calculated using the Mie-theory extinction coefficients depending on the aerosol refractive indexes and their hygroscopic properties.

As in POLDER data retrieval, the refractive index is fixed to $\mathrm{m}=1.47-0.01 \mathrm{i}$ and only particles smaller than $0.6 \mu \mathrm{m}$ in radius are considered. Since the refractive index depends on the aerosol composition and relative humidity (Hanel, 1976), a sensitivity study was performed in order to evaluate the impact of this assumption on AOT values: Varying the refractive index during our study period, characterized by dry atmospheric conditions, the simulated AOT values changed by less than $1 \%$.

\section{Results and discussion}

\subsection{Description of the August 2003 AOT episode from POLDER data}

The August 2003 pollution episode was characterized by exceptionally high aerosol optical thicknesses over Europe associated with high aerosol AOTs. The episode was particularly well captured by POLDER-2 instrument due to cloudless atmospheric conditions during this heatwave. Figure 1 shows the spatio-temporal evolution of the POLDER-derived AOTs over Europe from 1 to 15 August. The exceptionally wide spatial extent of this episode and the progressive accumulation of the aerosol load are clearly illustrated. The "background" AOTs increase from low values $(<0.025)$ at the beginning of the episode (1-5 August) to higher values (0.05-0.075) from 6 to 13 August (Fig. 1). Several AOT 

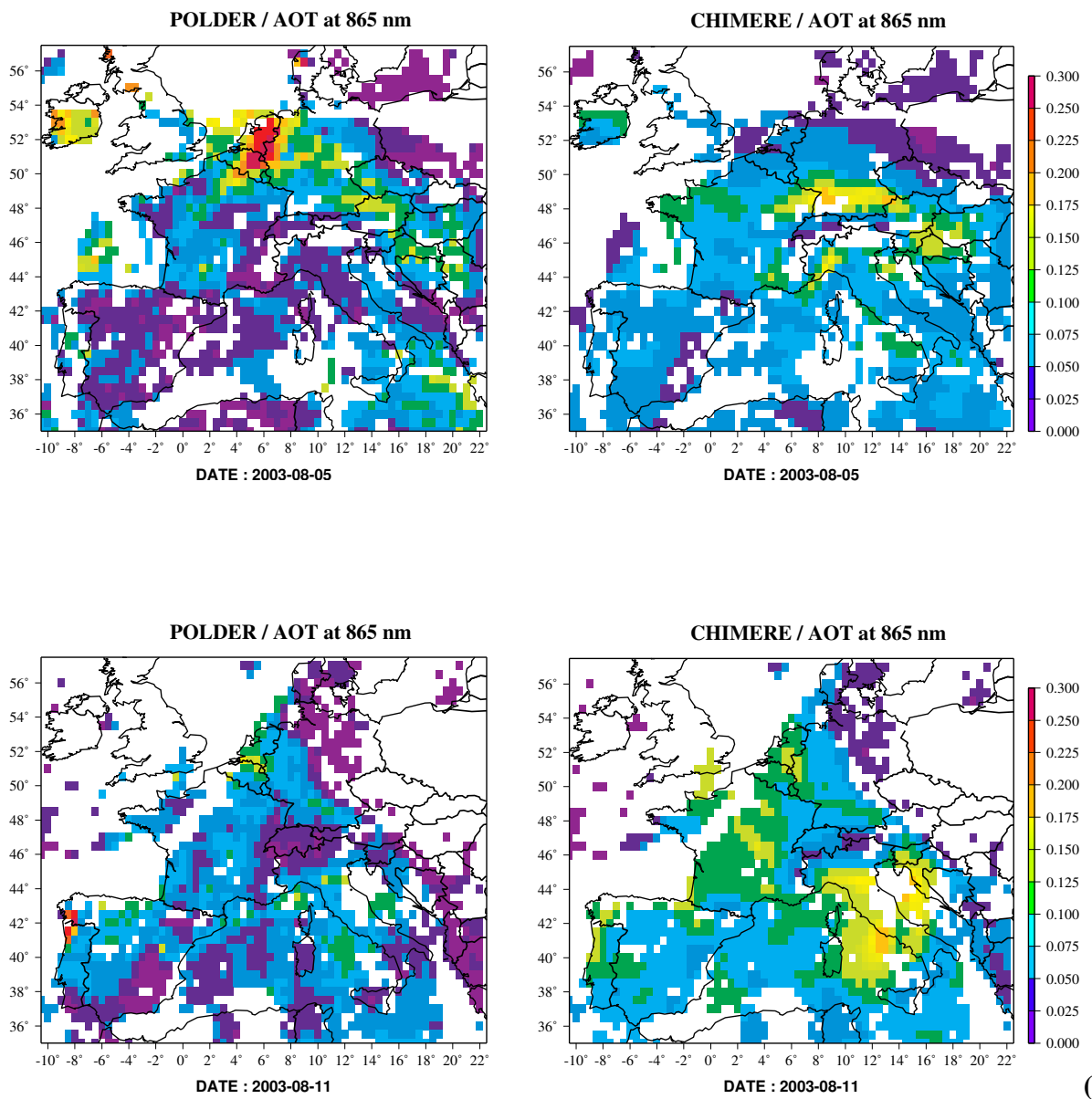

(a)
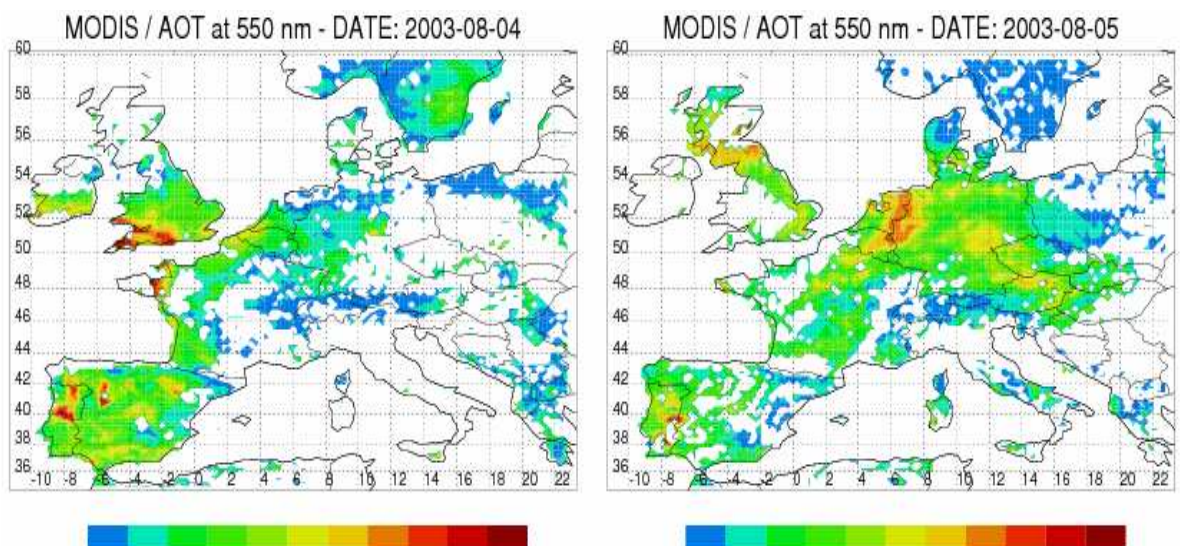

$\begin{array}{lllllllllllll}0.1 & 0.2 & 0.3 & 0.4 & 0.5 & 0.6 & 0.7 & 0.8 & 0.9 & 1.0 & 1.1 & 1.2\end{array}$

$\begin{array}{lllllllllllll}0.1 & 0.2 & 0.3 & 0.4 & 0.5 & 0.6 & 0.7 & 0.8 & 0.9 & 1.0 & 1.1 & 1.2\end{array}$

(b)

Fig. 2. (a) Geographic distribution of the fine mode aerosol optical thickness at $865 \mathrm{~nm}$ retrieved from the POLDER data (left) and simulated by CHIMERE model (right) over Europe on 5 and 11 August 2003. POLDER data are averaged to the grid cell of CHIMERE $(0.5 \times 0.5$ degree). (b) Geographic distribution of the aerosol optical thickness at $550 \mathrm{~nm}$ retrieved from the MODIS sensor over Europe on 4 and 5 August 2003. MODIS data account for both fine and coarse mode aerosols and are represented with $0.25 \times 0.25$ degree resolution.

peaks ( $>0.25$ ) could be noticed, especially on 3 and $4 \mathrm{Au}-$ gust over Portugal and on 5 August over The Netherlands
(Fig. 2). This last AOT peak moves towards Eastern and Southern Germany on 6 August, and probably towards Italy 
on 7 August. The episode ends on 14-15 August with the arrival of a weather system and rainy weather conditions.

The exceptional nature of this heat wave period in terms of aerosol optical thicknesses can be judged by comparing AOTs with the other summer-time data from the POLDER2 instrument. The mean AOT values from April to October over Europe are summarized in Table 1. The mean AOT observed from 4 to 13 August reaches 0.064 and is a factor of 2 higher than AOTs obtained during other summer months.

\subsection{Cases of 5 and 11 August}

We now examine in greater detail two interesting cases, 5 and 11 August. Figure 2a shows the spatial distribution of the aerosol optical thickness at $865 \mathrm{~nm}$ as observed by POLDER and simulated by CHIMERE model over Europe for these two days. In these figures POLDER data are averaged over the exact CHIMERE grid cells in order to facilitate comparison. On both days, POLDER AOTs exhibit more spatial variability than model simulations, with important AOT peaks ( $>0.25$ ) over The Netherlands or Ireland on 5 August and over Portugal on 11 August, and generally very low values $(<0.05)$ over southern Spain. The model AOTs are more homogeneous and generally higher $(0.05-0.2)$. On 5 August the simulated AOT map is fairly different from the observed one, while on 11 August the simulated and POLDER spatial structures are similar, with maxima over the Ruhr, southern Germany, central France, Portugal and off the southern Italian coast. However in both cases the simulated "background" AOTs are about twice as large as the POLDER satellite retrievals. On the contrary the 5 August high AOTs values are absent in the simulated AOT which is five times smaller, both in amplitude and spatial structure. Missed patches of high AOTs are also present on 4 and 6 August. The comparison with MODIS data shown in Fig. $2 b$ also confirms the presence of high AOT values ( $>0.9$ at $550 \mathrm{~nm}$ ) over Northern Europe on 4-5 August, showing that these features are real and must be understood.

\subsection{Statistical comparisons}

We now examine the results of the comparisons between simulated and observed AOTs in a statistical manner. Problems revealed by Fig. 2a are quite general, as suggested by Fig. 3, which shows daily model and observed spatial AOT averages and the spatial correlation between the two fields during the heat wave period. The analysis is also performed over specific regions. According to Fig. 3a, half of observed AOT data over Europe ranges from 0.025 to 0.08 , with a mean AOT of 0.06 , while model AOTs vary from 0.05 to 0.1 , with mean AOT greater than 0.08. The model overestimates the mean AOT values by about $30 \%$ and the spatial correlation reaches 0.4 . The time variability is fairly well reproduced by the model during the episode with an increase of AOT values due to the accumulation of the aerosol load.
Two periods can be distinguished: the period from 3 to 6 August when model and observations have similar mean AOT values, but poor correlation coefficients (less than 0.3); and the period after 7 August characterized by higher correlations (0.4-0.6) and a model positive offset of 30-50\%. Furthermore, the separate comparisons over ocean (Fig. 3b) and land (Fig. 3c) surfaces give similar results about average AOTs. This indicates at least that the land surface and ocean AOT retrieval algorithms are consistent in terms of average AOTs. However the spatial correlations between modeled and observed data are significantly higher over the ocean than over land, in a nearly systematic manner. This could be due to a higher uncertainty in the POLDER retrieval over land (Deuzé et al., 2001) discussed in next section.

In order to define European areas with similar behavior in terms of model/observation comparisons, we calculate the spatial distribution of correlation coefficients obtained between observed and simulated AOTs. This correlation is now calculated as a time correlation for $1.5^{\circ} \times 1.5^{\circ}$ grid cells, each containing nine model grid points. The correlation distribution is shown in Fig. 4. The spatial heterogeneity of correlation coefficients shows the regions where major inconsistencies between model and satellite data are expected. Lower correlations $(<0.3)$ are found over the Benelux countries, the North of Portugal and the Eastern Mediterranean where generally higher AOT values are observed.

The quantitative comparison performed over the regions highlighted in Fig. 4 is shown in Figs. 3d-f. Again two distinct problems are identified: i) the general positive difference between model and POLDER AOTs during the whole comparison period and over all regions, and ii) the inability of the model to simulate the AOT peaks observed on 5-6 August over Northern Europe and 3 April 2005 over Portugal. Over Mediterranean areas the model exhibits a generally positive bias as compared to POLDER. It must be noticed that our results are not affected by the presence (or the absence) of Saharan dust particles, as the associated aerosol particles are mostly in the coarse mode while the AOT thickness discussed here only account for aerosols in the fine mode. Therefore the relatively low correlations over this area cannot be due to the difficulty in simulating Saharan dust. We now give tentative explanations for these problems.

\subsection{On the origin of the systematic difference between model and POLDER data}

The systematic difference between average model and observed AOTs suggests that either the model significantly overestimates the aerosol load in these regions, or the POLDER retrievals underestimate the background aerosol levels due to uncertainties in the aerosol retrieval algorithms. In order to answer this question, we intercompare model and observations coming from POLDER and AERONET only when and where these data are simultaneously available during the heat wave event. Results are summarized in 

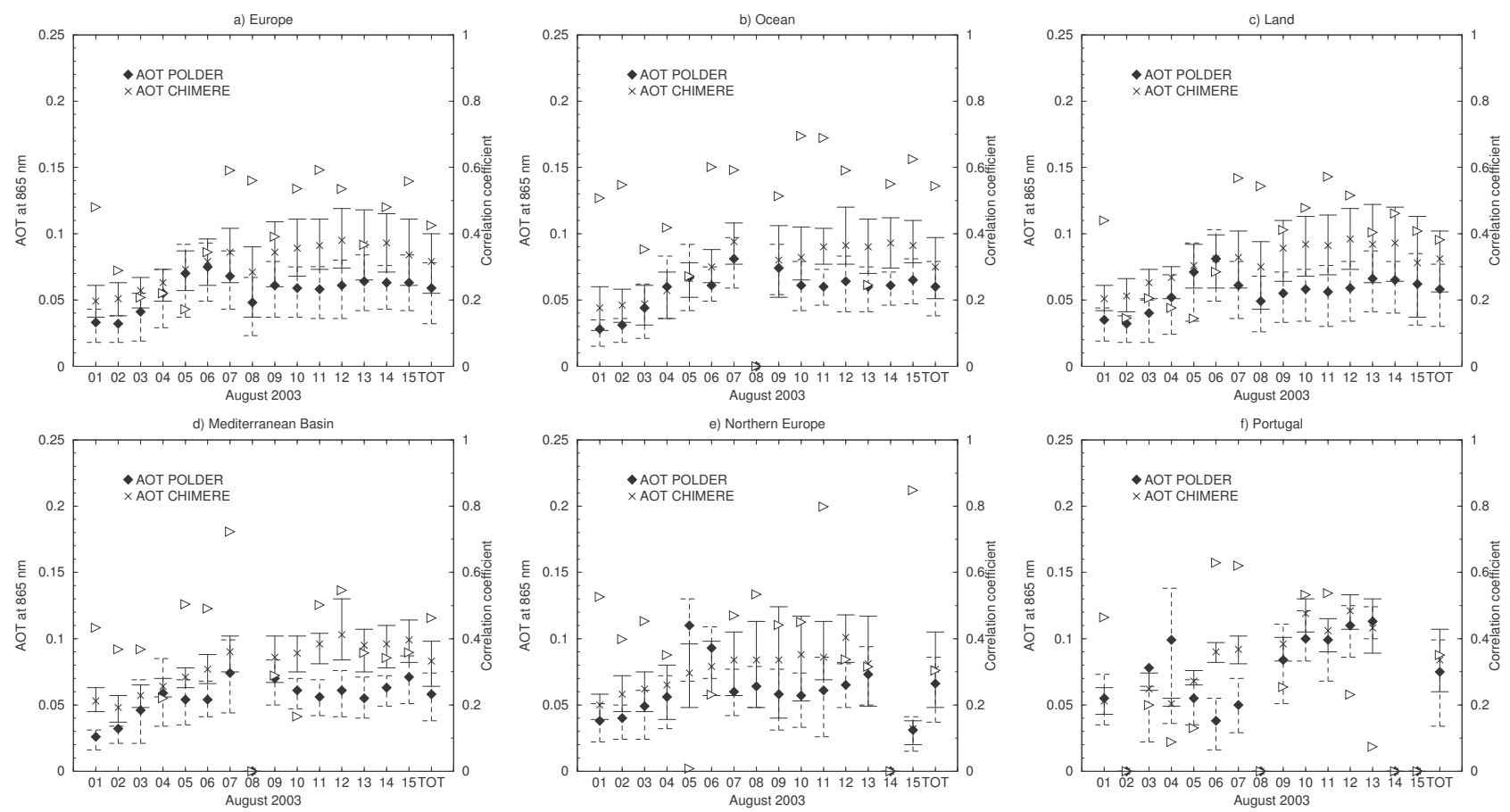

Fig. 3. Comparison of simulated vs. satellite retrieved spatial mean AOT at $865 \mathrm{~nm}$ and spatial correlation (a) over the whole European model domain; (b) over ocean only; (c) over land only; (d) over Mediterranean basin; (e) over Northern Europe and (f) over Portugal. These regions are defined in Fig. 4. The intervals represent 25 and 75 percentiles. Correlation coefficients are indicated by triangles.

Fig. 5. As for model-POLDER AOT comparisons we observe a clear systematic difference between POLDER and Sun photometer AOTs, even though the correlation between the two sets of data is relatively high, 0.72. CHIMERE AOTs compare much better (in amplitude) with AERONET AOTs than with POLDER AOTs. The CHIMERE/POLDER and CHIMERE/AERONET correlation coefficients are comparable and reach respectively 0.64 and 0.61 if the episode of 5-6 August is excluded. This indicates that the previously discussed systematic model overestimation of satellite data may be related to a negative bias in POLDER retrievals. On Fig. 5b we display the ratio of the POLDER- to AERONETderived AOT data as a function of the Angström exponent. Values below unity correspond to POLDER underestimation. The Angström exponent indicates that the POLDER underestimation is more important for larger aerosol particles in the accumulation mode than for smaller ones. The underestimation of the POLDER AOT at $865 \mathrm{~nm}$ is consistent with previous POLDER validation studies (Deuzé et al., 2001) and can be explained by large uncertainties in the aerosol retrievals from satellite data. The satellite underestimation could be associated with numerous factors such as (i) uncertainties in the surface polarization correction, (ii) underestimation in the detection of fine fraction of dust particles, or (iii) incorrect choice of the aerosol algorithm used for the retrieval of aerosol optical properties. In this study, the main error comes from inaccuracies in the surface polarization correction that

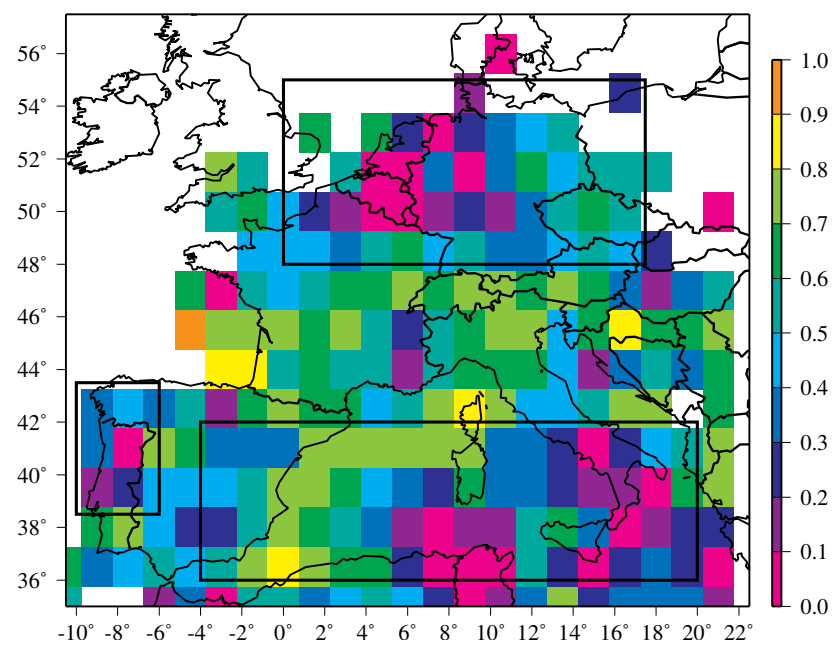

Fig. 4. Time correlations between simulated and POLDER retrieved AOT across Europe during the summer 2003 heat wave (from 1 to 15 August 2003).

reaches its maximum over urban surfaces. Simultaneously, background AOT is generally not very high in the region considered. Combination of these two factors leads to strong underestimation of AOT Deuzé et al. (2001) and Nadal and Bréon (1999). Another potential error is related to the occurrence of low polarizing particles (dust particles) that also 

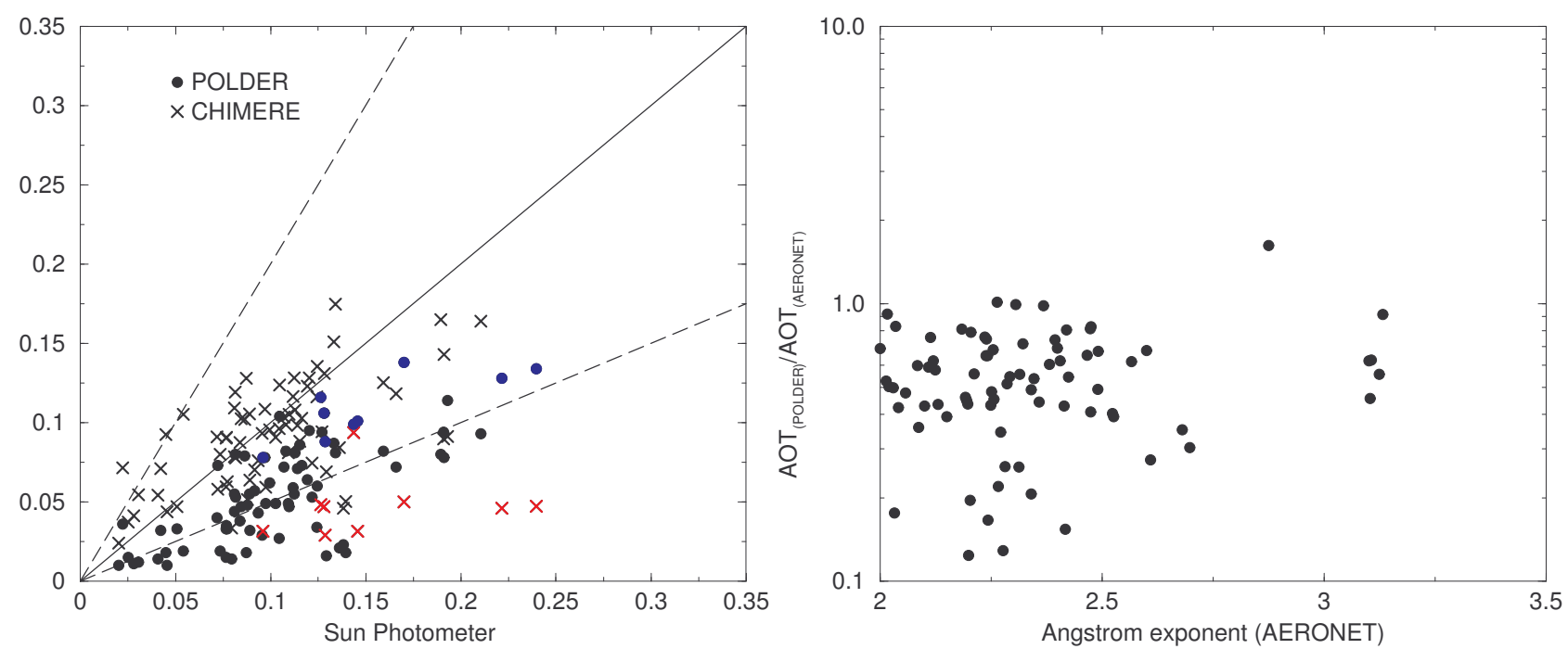

Fig. 5. (a) Scatter plots of satellite (dots) and model (crosses) retrieved vs AERONET observed AOT at $865 \mathrm{~nm}$. Color points correspond to the stations influenced by smoke plume advection that occurred on 5 and 6 August. The number of used data is 78 . Solid line is the 1:1 ratio and dotted lines are a factor of 2 departure. (b) The ratio of the AOT derived from POLDER and AERONET as a function of the Angström exponent. The location of AERONET stations is indicated in Fig. $7 \mathrm{~b}$.

affects the retrieval accuracy. However, the impact of this latter error is limited regarding the geographical location (Europe) and the studied period. Figure 5a, and the comparison with AERONET data shows the probable absence of bias in the model AOTs. However, as discussed below, the model largely underestimates some of the Sun photometer data on 5 and 6 August, as it did with the POLDER data. This problem is discussed now.

4.5 AOT peaks and the spread of smoke particles from Portugal forest fires

Comparison results obtained for Northern Europe (Fig. 3e) and the Portugal region (Fig. 3f), show the inability of the model to reproduce the intense AOT peaks observed during the period from 3 to 6 August. These exceptionally high AOT values are found in the satellite retrievals on 3 and 4 August over Portugal and on 5 and 6 August over Benelux. The poor agreement between model and satellite data also results in low correlation coefficients.

Numerous factors could be incriminated for these problems such as (i) cloud contamination in the POLDER data or (ii) errors in model simulations including uncertainties in aerosol parameterisation, missing processes or sources. The satellite data for this period have been carefully screened. We examined the fine mode Angström exponent which is an indicator of the particle size and could be used to detect the presence of clouds and dust aerosols, associated with lower Angström values, typically from 0.3 to 1 . The POLDERderived Angström exponent ranges from 2 to 2.5 and indicates that aerosols over Portugal and The Netherlands are mainly composed of small particles present in polluted air masses, eliminating the possibility of cloud and dust contamination. Several reasons led us to believe that the model is missing a key source of aerosols during this period, the violent wildfires that occurred in many areas, especially in central Portugal. First, routine ground-based aerosol measurements (air quality monitoring, http://www.lml.rivm.nl/) do not display particularly elevated concentrations of aerosol particles $\left(\mathrm{PM}_{10}\right)$ on 5 August. The model simulated aerosol ground concentrations are of comparable magnitude to the observed ones (in the range $15-35 \mu \mathrm{g} / \mathrm{m}^{3}$ at 11:00 UTC). Thus anthropogenic pollution is not responsible for the high AOT values above The Netherlands, and high AOTs are most likely due to elevated aerosol layers. The presence of such elevated aerosol layers is confirmed by backscatter lidar vertical profiles at $1064 \mathrm{~nm}$ (Fig. 6) obtained at Cabauw (51.97N, 4.93E, The Netherlands) on 5 August at 11:00 UTC: profiles clearly show aerosols capped in a layer ranging from 3 to $4 \mathrm{~km}$.

Since these aerosols are not locally produced, they are certainly long-ranged transported. In order to verify the hypothesis of a Portuguese origin, we calculated backtrajectories with the NOAA Hysplit model (Hybrid SingleParticle Lagrangian Integrated Trajectory, http://www.arl. noaa.gov) ending over the Netherlands on 5 August at altitudes of 3 to $4 \mathrm{~km}$. The back-trajectories (not shown) clearly indicate that the elevated aerosol layer located over The Netherlands crossed the Portuguese forest fire zone and also the high AOT zone located over the north of Portugal on 2-3 August. According to MODIS satellite images, during this period ( 2 and 3 August) the north of Portugal faced an extreme forest fire event that generated significant smoke 


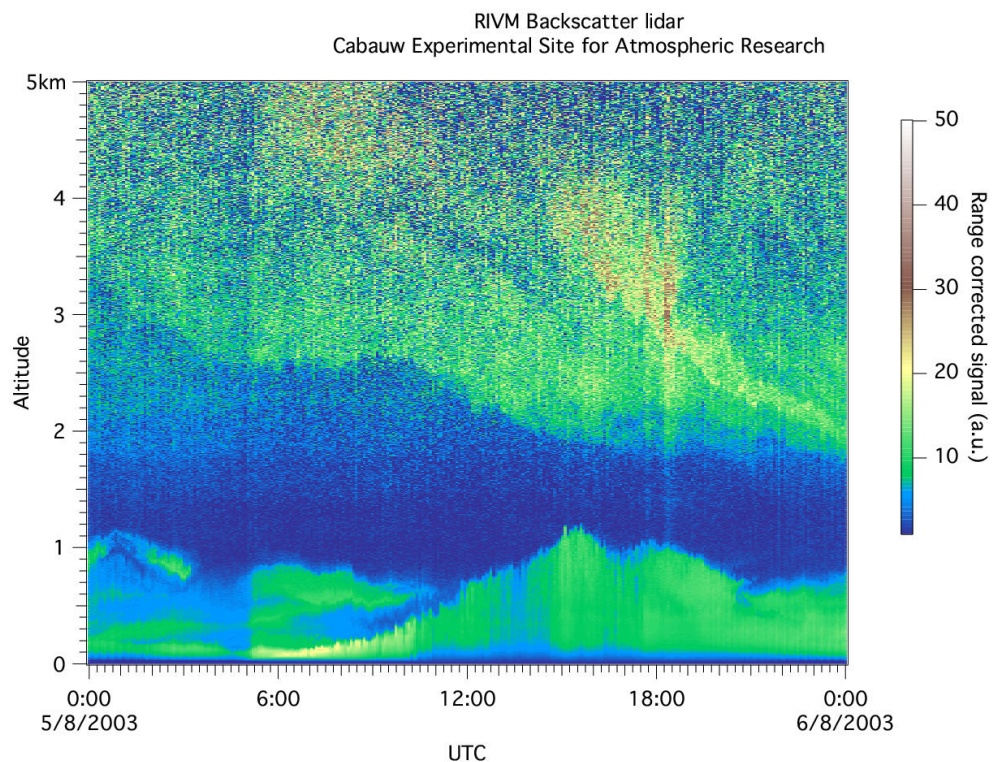

Fig. 6. Diurnal evolution of the aerosol vertical distribution on 5 August 2003 over Cabauw, The Netherlands. The color code in arbitrary units displays the relative strength of the backscatter. An elevated aerosol layer, decoupled from the planetary boundary layer is present above $2 \mathrm{~km}$ altitude.
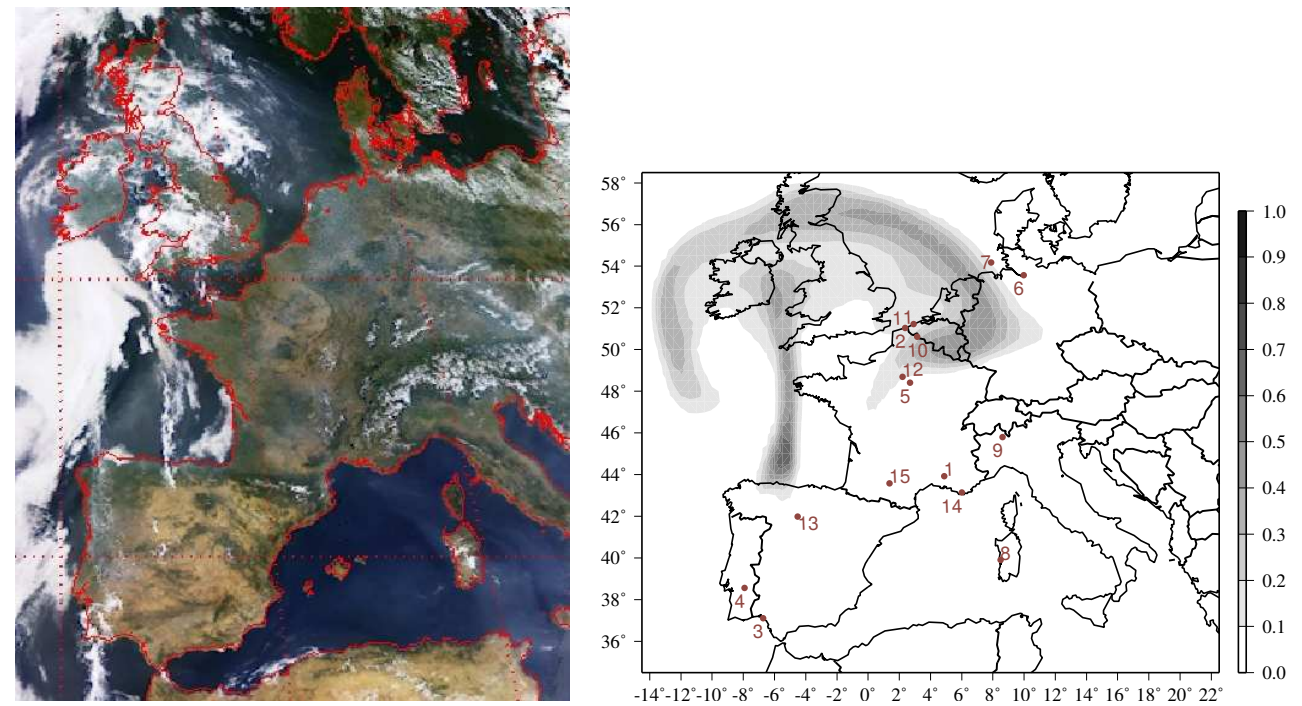

Fig. 7. (a) POLDER-2 image (composite Red-Green-Blue) over Europe on 5 August (courtesy of LOA and CNES/NASDA). (b) Advection of smoke particles coming from forest fires in Portugal, over Northern Europe on 5 August as simulated by CHIMERE model between 3000 and $4000 \mathrm{~m}$. AERONET stations used in this study are also indicated (including ${ }^{1}$ Avignon (9), ${ }^{2}$ Dunkerque (4), ${ }^{3} \mathrm{El} \mathrm{Arenosillo} \mathrm{(5),}$ ${ }^{4}$ Evora (7), ${ }^{5}$ Fontainebleau (2), ${ }^{6}$ Hamburg (5), ${ }^{7}$ Helgoland (2), ${ }^{8}$ IMC Oristano (5), ${ }^{9}$ Ispra (10), ${ }^{10}$ Lille(3), ${ }^{11}$ Oostende(3), ${ }^{12}$ Palaiseau (6), ${ }^{13}$ Palencia (1), ${ }^{14}$ Toulon (7), ${ }^{15}$ Toulouse (8); the number of AERONET data available at each station is indicated in brackets).

plumes (http://rapidefire.sci.gsfc.nasa.gov/) that could have been transported far away from their sources. This suggests that the enhanced AOTs observed in Portugal and over The Netherlands have the same origin: the Portuguese forest fires.

The POLDER image of 5 August (Fig. 7a) also indicates that smoke from the fires was transported across the Bay of
Biscay to Northern Europe. Parts of the aerosol cloud can be seen over the Benelux area as well as over the British Isles and Ireland. We confirmed this finding by carrying out "passive tracer" runs with the CHIMERE model. A passive tracer (no chemistry and deposition) was introduced in the model in order to account for the emission of primary aerosols due 


\section{Portugal $[-8 W, 40 N]$}

Aug. 2, 2003, 11:00

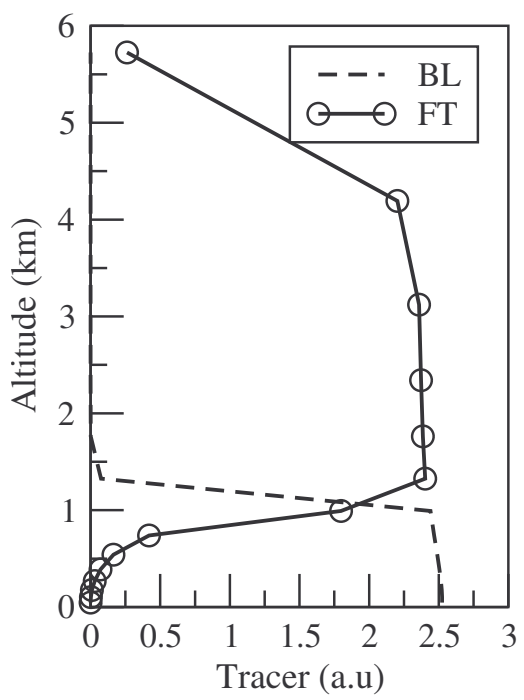

Ireland $[-7 \mathrm{~W}, 54 \mathrm{~N}]$

Aug. 4, 2003, 18:00

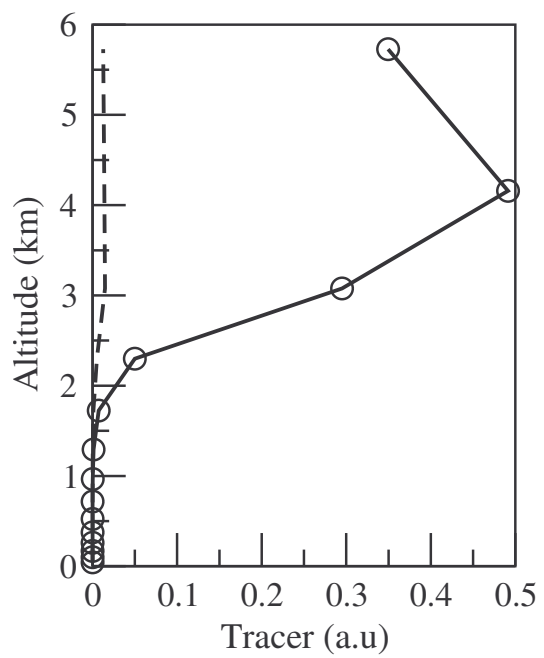

Atlantic sea $[-6 \mathrm{~W}, 44 \mathrm{~N}]$

Aug. 4, 2003, 12:00

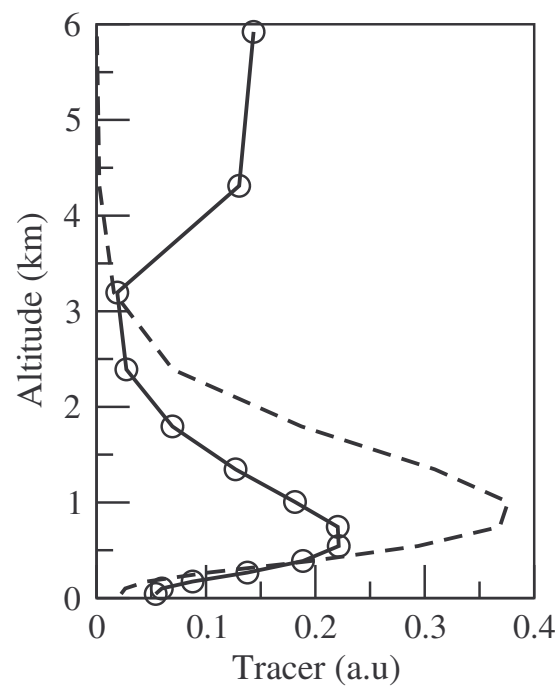

The Netherlands [5E,52N]

Aug. 5, 2003, 11:00

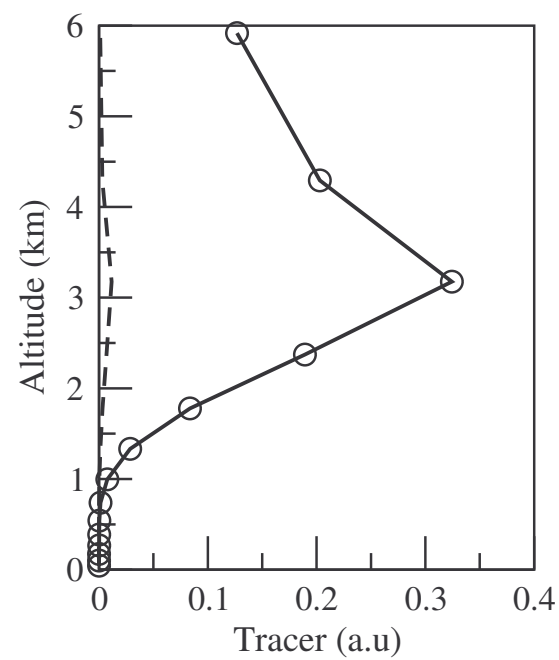

Fig. 8. Transport of smoke particles from forest fires in Portugal through Europe as simulated by CHIMERE model. Vertical profiles of boundary layer (BL) and free troposphere (FT) emitted tracers (a.u: arbitrary unit) are presented at different locations.

to forest fires and their subsequent transport in the atmosphere. The tracer was emitted with an arbitrary amplitude within the lower troposphere column (ground to $4 \mathrm{~km}$ ) from 2 (10:00 UTC) to 4 August (23:00 UTC) over the model grid cells corresponding to active fire spots $\left(-8^{\circ} \mathrm{W}, 40^{\circ} \mathrm{N}\right)$ detected by MODIS Rapid Response System (NASA/GSFC, http://rapidefire.sci.gsfc.nasa.gov/). Figure 7b shows the location of the simulated smoke plume on 5 August over Europe. The tracer has been actually transported to an altitude of $3-4 \mathrm{~km}$ in the anticyclonic flux from Portugal to North- ern Europe, across Great Britain. These results are consistent with previous back-trajectories, lidar data, and the similarity between the structures in Figs. 7a and b is striking. This model result, together with the other information we had, confirm that carbonaceous aerosols advected from forest fires in Portugal are the most probable origin of the high AOT observed over The Netherlands on 5 August. 


\subsection{Evidence of elevated smoke injection height}

Another important finding concerns the altitude of tracer injection required for the propagation of the fire smoke. Due to their high temperature, fire-emitted carbonaceous particles are directly injected into the atmosphere up to 3 to $4 \mathrm{~km}$ altitude and may be transported for several hundred kilometers. Additional tracer sensitivity tests demonstrate that the classical convective scheme used in the model is not efficient enough to represent the thermal updraft of fire smoke plumes. In order to determine the original altitude of the emitted smoke plume, tracers were emitted function of the atmospheric stability (Fig. 8), respectively within the boundary layer (BL) and into the free troposphere (FT). Particles emitted in the boundary layer usually stay in the mixed layer during the day and are partially capped into a residual layer when the boundary layer collapses and could be long-ranged transported. Figure 8 shows that the boundary layer tracer (BL) is transported further to the Atlantic Ocean and does not explain the concentrations observed over the Netherlands. Only the tracer (FT) directly emitted to the free troposphere reaches the Netherlands and explains the patterns observed in POLDER data. This experiment constitutes a strong evidence that smoke particles emitted at the surface are directly injected into the free troposphere up to $3-4 \mathrm{~km}$ altitude and undergo long-range transport to Northern Europe. Finally, it is important to notice that a model upper boundary of $500 \mathrm{hPa}$ could be a limiting factor when studying free tropospheric transport of smoke particles since these particles can be convected to much higher altitudes. Additional sensitivity studies regarding to the model's top level altitude revealed that the long-range transport of particles is not significantly changed during our specific case study by increasing the model top altitude. However, considering the real wild fire emissions in further model studies will require increasing the model top level at least up to $300 \mathrm{hPa}$.

\section{Summary and Conclusion}

This study described the aerosol optical thicknesses encountered during the great European heat wave of August 2003 by comparing data derived from the POLDER-2 satellite sensor, the AERONET ground-based measurements and simulations from the regional chemistry-transport model CHIMERE. It is demonstrated that the period from 1 to 15 August had an exceptionally high load of aerosol: the observed mean AOT was a factor of 2 higher than during other summer 2003 months, which were also generally polluted months.

The model/observation comparison shows a fair agreement between the main spatial structures. However the model accumulation-mode AOTs are systematically higher than the POLDER AOTs (at $865 \mathrm{~nm}$ ). The comparison with AERONET ground-based measurements indicates that this difference results from a negative bias in the POLDER re- trievals. This bias seems to occur both for land and ocean types of surfaces and was reported in previous studies (Deuzé et al., 2000, 2001). The amplitude of the simulated AOTs is in better agreement with sun photometer data than with POLDER data. However POLDER data have a spatial coverage that allows the evaluation of the model at the scale of the European continent on a grid while AERONET data do not.

There are features that are not reproduced at all by the model, especially during the 2-6 August period over Portugal, The Netherlands, parts of the British Isles and Ireland, where AOTs are very high by patches. We demonstrate that these aerosol "clouds" are likely to originate from the intense forest fires that occurred over Portugal at the beginning of August 2003. The smoke particles generated by the forest fires are transported far away from their sources and affect significantly the aerosol optical properties over Europe during the heat wave episode. The current model does not account for sporadic emissions of aerosols due to forest fires or dust events and therefore it underestimates the simulated aerosol optical properties during the beginning of the heat wave period.

This comparison highlights the unique advantage of using satellite data to assess model performances, but also the difficulties and limits of this type of verification due to large uncertainties involved in satellite and model retrievals of aerosol optical properties.

Acknowledgements. The authors acknowledge R. Armante and C. Pietras, Pierre-Simon Laplace Institute, France, S. Massie and J. Lee-Taylor, National Center for Atmospheric Research (NCAR), USA, for their scientific and technical support. We are grateful to the Centre National d'Etudes Spatiales (CNES) for providing POLDER data used in this study. We also thank AERONET Principal Investigators for collecting and providing the Sun photometer data needed to accomplish this study. The MODIS instrument is operated by the National Aeronautics and Space Agency (NASA), which we acknowledge for their data. This research has been financially supported by ADEME and AIRPARIF.

Edited by: K. Carslaw

\section{References}

Bessagnet, B., Hodzic, A., Vautard, R., Beekmann, M., Cheinet, S., Honoré, C., Liousse, C., and Rouil, L.: Aerosol modeling with CHIMERE - Preliminary evaluation at the continental scale, Atmos. Environ., 38, 2803-2817, 2004.

Chiappello I., Goloub P., and Tanré D., et al.: Aerosol detection by TOMS and POLDER over oceanic regions, J. Geophys. Res. Atmos., 105(D6), 7133-7142, 2000.

Chin, M., Ginoux, P., Kinne, S., Torres, O., Holben, B. N., Duncan, B. N., Martin, R. V., Logan, J. A., Higurashi, A., and Nakajima T.: Tropospheric aerosol optical thickness from the GOCART model and comparisons with satellite and sun photometer measurements, J. Atmos. Sci., 59, 461-483, 2004. 
Deschamps, P. Y., Bréon, F. M., Leroy, M., Podaire, A., Bricaud, A., Buriez, J. C., and Seze, G.: The POLDER Mission: Instrument Characteristics and Scientific Objectives, IEEE Trans. Geosci. Rem. Sens. 32, 598-615, 1994.

Deuzé J. L., Goloub P., Herman M., Marchand A., Perry G., Susana S., Tanré D.: Estimate of the aerosol properties over the ocean with POLDER on ADEOS-1, J. Geophys. Res., 105(D12), 15 329-15 346, 2000.

Deuzé J. L. et al.: Remote sensing of aerosols over land surfaces from POLDER-ADEOS-1 polarized measurements, J. Geophys. Res., 106(D5), 4913-4926, 2001.

Goloub P. and Arino O.: Verification of the consistency of POLDER aerosol index over land with ATSR-2/ERS-2 fire product, Geophys. Res. Lett., 27(6), 899-902, 2000.

Hänel, G.: The properties of atmospheric aerosols as functions of the relative humidity at thermodynamic equilibrium with the surrounding moist air, Adv. Geophys. 19, 73-188, 1976.

Herman, M., Deuzé, J. L. Devaux, C., Goloub, P., Bréon, F. M., Tanré, D.: Remote sensing of aerosols over land surfaces including polarization measurements and application to POLDER measurements, J. Geophys. Res., 102(D14), 17 039-17 050, doi: 10.1029/96JD02109, 1997.

Hodzic, A., Chepfer, H., Vautard, R., Chazette, P., Beekmann, M, Bessagnet, B., Chatenet B., Cuesta, J., Drobinski, P., Goloub, P., Haeffelin, M., and Morille, Y.: Comparison of aerosol chemistrytransport model simulations with lidar and sun-photometer observations at a site near Paris, J. Geophys. Res., 109, D23201, doi:10.1029/2004JD004735, 2004.

Holben, B. N., Eck, T. F. Sluster, I. Tanré, D., Buis, J. P., Setzer, A., Vermote, E., Reagan, J. A., Kaufman, Y. J., Nakajima T., Lavenu, F., Jankowiak, I., and Smirnov, Z.: AERONET-A federated instrument network and data archive for aerosol characterization, Rem. Sens. Environ., 66, 1-16., 1998.

Kaufman, Y. J., Tanré, D., and Boucher, O.: A satellite view of aerosols in the climate system, Nature, September 2002.

King, M. D., Kaufman, Y. J., Tanré, D., and Nakajima, T.: Remote sensing of Tropospheric aerosols from Space: Past, Present, and Future, Bull. Amer. Met. Soc., 80, 2229-2259, 1999.
Leroy, M., Deuzé, J. L., Bréon, F. M., Hautecoeur, O., Herman, M., Buriez, J. C., Tanré, D., Bouffies, S., Chazette, P., and Roujean, J. L.: Retrieval of atmospheric properties and surface bidirectional reflectances over the land from POLDER, J. Geophys. Res., 17 023-17 037, 1997.

Li, Z., Goloub, P., Devaux, C., Gu, X., Qiao, Y., Zhao, F., Chen, H. B, and Chatenet, B.: Aerosol polarized phase function and single-scattering albedo retrieved from ground-based measurements, Atmos. Res., 71, 233-241, 2004.

Myhre, G., Stordal, F., Johnsrud, M., Ignatov, A., Mischenko, M. I., Geogdzhayev, I. V., Tanré, D., Deuze, J. L., Goloub, P., Nakajima T., Higurashi, A., Torres, O., Holben, B.: Intercomparison of satellite retrieved aerosol optical depth over the ocean, J. Atmos. Sci., 61(5), 499-513, 2004.

Nadal, F. and Bréon, F. M.: Parameterization of surface polarized reflectance derived from POLDER spaceborne measurements, IEEE Trans. Geosci. Rem. Sens., 37, 1709-1718, 1999.

Rasool, I., Baldi, M., Wolter, K., Chase, T. N., Otterman, J., and Pielke, R. A.: August 2003 heat wave in Western Europe, An analysis and perspectives, European Meterological Society (EMS) 4th Annual Meeting - Part and Partner: 5th Conference on Applied Climatology (ECAC), Nice, France, 26-30 September, J. Geophys. Res., 2004.

Remer, L. A., Tanré D., Kaufman, Y. J., Ichoku, C., Mattoo, S., Levy, R., Chu, D. A., Holben, B. Dubovik, N. O., Ahmad, Z., Smirnov, A., Vanderlei Martins, J.,and Li, R.-R.: Validation of MODIS Aerosol Retrieval Over Ocean, Geophys. Res. Lett., 29, doi:10.1029/GL013204, 2002.

Schmidt, H. and D., Martin: Adjoint sensitivity of episodic ozone in the Paris area, to emissions on the continental scale, J. Geophys. Res., 108(D17), 4313, 2003.

Tanré, D., Bréon, F. M., Deuzé, J. L., et al.: Global observation of anthropogenic aerosols from satellite, Geophys. Res. Lett, 28(24), 4555-4558, 2001.

Vautard, R., Bessagnet, B., Chin, M., and Menut, L.: On the contribution of natural Aeolian sources to small particle concentrations in Europe, testing hypotheses with a modelling approach, Atmos. Environ., 39(18), 3291-3303, 2005. 